\title{
The Weak Link: Diagnosing Political and Social Factors in China’s Environmental Issue
}

\author{
Xiaofan Li \\ Institutional Research and Assessment, Washington DC, USA \\ Email: Li@cua.edu, xiaofanlixf@gmail.com
}

Received August $17^{\text {th }}, 2013$; revised September $18^{\text {th }}, 2013$; accepted September $28^{\text {th }}, 2013$

\begin{abstract}
Copyright (C) 2013 Xiaofan Li. This is an open access article distributed under the Creative Commons Attribution License, which permits unrestricted use, distribution, and reproduction in any medium, provided the original work is properly cited.
\end{abstract}

\begin{abstract}
China's thriving economy takes a toll on its environmental sustainability, and recent decades have witnessed an irreversible degradation in China's environmental conditions. Meanwhile, the environmental issue in China is embedded in a large and complex political and social context that has been undergoing continual and far-reaching transformations. With an attempt to diagnose the weak link and to shed light on solutions for China's environmental issue, this article explores and analyzes an array of political and social factors: changes in China's environmental policies and political orientations, conflicts between economic growth and environmental protection, political decentralization and its impact on the environmental issue, and China's civil society’s role in public awareness and support for environmental protection.
\end{abstract}

Keywords: China; Environmental Protection; Politics; Decentralization; Policies; Civil Society

\section{Introduction}

China has increasingly become a global economic powerhouse. However, its economic boom is gained at the cost of sacrificing extensive environmental sustainability, and recent decades have witnessed a tremendously intractable degradation in natural and ecological environment in China.

Environmental problems are prevalent throughout most of China: deforestation, desertification, soil erosion, loss of arable land, air pollution, and water contamination (Banister, 1998; Boxer, 1989; Lo \& Fryxell, 2003; Wan, 1997). According to a report by the State Environmental Protection Administration (SEPA) 国家环境保护总局, 3\% of China’s GDP in 2004 was lost due to environmental destruction (State Environmental Protection Administration, 2004). The situations have worsened and the ecological footprints of China's population have been substantially deepened during the reform years, as numerous industrial and economic activities have been undertaken with little or no concern about environmental quality.

However, the environmental issue in China is embedded in a large and complex political and social context that has been undergoing continual and far-reaching transformations in terms of political agenda and social values. These changes are "so profound, so rapid and contradictory, that the state, through its environmental policy, has had difficulty in identifying the root structural causes of its environmental problems, let alone mitigating them” (Muldavin, 2000: p. 245). Meanwhile, politics in China tends to give priority to economic development and policies of environmental protection are often ambiguous and irresolute. Various institutional factors hinder a nationwide coordination and endeavor. Lo \& Fryxell (2003: p. 82) attributed this to "China's fragmented bureaucracy, political obstruction of the more powerful ministries, and a shortage of resources". More- over, subject to political coercion, China's underdeveloped civil society adds more obstacles to the cause of environmental protection by blocking free avenues of public advocacy, civic engagement, and development of non-governmental organizations (NGOs). This paper attempts to shed light on solutions for China's environmental issue by exploring and analyzing an array of political social factors. First, it examines the changes in China's environmental policies and political orientations; second, it discusses the conflicts between economic growth and environmental protection, political decentralization and its impact on the environmental issue; third, it explores the civil society in China and its role in public awareness and support for the cause of environmental protection.

\section{Environmental Protection Policies in China (1950-Present)}

Policymaking in the environmental issue in China has been characterized as an oscillating commitment by the state government, mainly due to its concentration on propelling economic growth, with many other issues in the society often being eclipsed by this orientation.

About a decade after the Communist Party took over the regime, China's first milestone environmental policy was instituted in the 1950s, comprehensively aiming to address the issues of flooding control, hydropower construction, river channels, and rural and urban water supply (Boxer, 1989; Ross, 1998). During the subsequent two decades, the tumultuous "Cultural Revolution" impeded substantial commission in environmental protection. In the mid-1970s when the turmoil was dying down, concerns over the environmental conditions began to resurface and a series of decrees were enacted to safeguard the environment and mitigate damage. Half of them comprised 
concrete plans of environmental remediation, and the rest were pertinent to procedures and responsibilities of government administration and enforcement (Palmer, 1998).

By the 1980s, environmental protection agencies at the national, provincial, and local levels had stepped up their coordinating efforts in combating environmental peril in China. More importantly, the state government began to emphasize the notion of "sustainable development", a political propaganda landmark in which "development" was re-defined as "meeting the needs of the present without compromising the ability of future generations to meet their own needs” (Brundtland, 1987: p. 91).

Since 1990, funds dedicated to environmental protection in China have been augmented, underscoring its commitment to this issue. The expenditures for treating waste water and solid dregs rose from 4.5 billion yuan (approximately US\$64 million) to 9.9 billion yuan (US\$17 million) within 5 years (China Daily 中国日报, 2005). Between 2001 and 2005, as part of the state’s panoramic Ninth Five-Year Plan, nearly one percent of the GDP was appropriated to tackle the environmental problems. This was almost twice as much as the total spending on environmental protection in the preceding three consecutive FiveYear Plans (1986-2000) combined. Collateral consequences were achieved in two aspects: one was a heightened public awareness of environmental protection, and the other was a more developed official channel of mobilizing funding and resources for environmental protection programs (Jahiel, 1997).

In theory, China's environmental policies are seemingly important and meaningful, and it should be able to ameliorate the deteriorating environment if these policies were effectively carried out (Banister, 1998; Schwartz, 2004). Schwartz (2004) put forth three preconditions that successful jurisdiction should satisfy: first, consent from central leadership; second, priority given by the top leaders; and third, compliance by the local leaders (Schwartz, 2004: p. 29). However, the emphasis on economic advancement makes it difficult for environmental policies to be completely and effectively implemented. On the other hand, policies in this field tend to be very acquiescent and non-confrontational (Lo et al., 2000). Thus violators survive and thrive with little solid and effective intervention from either government institutions or environmental agencies. For instance, countless township and village enterprises laden with pollution have mostly been able to minimize sanctions by the environmental institutions, because these low-tech, labor intensive factories absorb large labor surplus with low education level and minimal technical skills, and contribute one-third of the annual GDP of the country (Tilt, 2010). Closing them down would conceivably lead to vast layoffs and social unrest. In addition, many foreign-invested companies ostracized by their home countries because of their environmental infractions have found a foothold to operate in China. In 2007, the computer manufacturer, Hewlett Packard (HP), promised to cease the production of computers containing harmful chemicals, primarily BRF and PVC, in Chinese market by 2009. However, HP covertly revised this deadline to "2011" on their website without any formal announcements to the public in 2009, nor did they have any specific timeline of the former decision. Regardless of the disapproval and complaints from the public, HP has continued its production and sale of this kind of computers in China since then (China Daily 中国日报, 2011).

Internationally, China's stance toward cross-national collaboration on the environmental issue has been inconsistent and even evasive. China was the first country in the world to ratify the United Nations Framework Convention on Climate Change (UNFCCC) in 1992 (Wan, 1998). Nonetheless, China in fact has not actively fulfilled the promises that it made in global negotiations, and it has begun to retrograde in recent years. In 2004 China withdrew from the Kyoto Protocol, a key part of UNFCCC aiming to reduce greenhouse gas emissions through international cooperation (Jeon \& Yoon, 2006). Breaking away from the binding duties that Kyoto mechanism imposed on nations, China attempted to seek a coalition with other developing countries as leverage resisting foreign pressures. The major reason is that China is still reluctant to sacrifice its economic development for the costly accountabilities of preserving environmental health (Wan, 1998). To some degree, the commitment that it has made in environmental protection is intended to subdue international and domestic criticism, reinforce its authoritarian reign, and enhance its powerhouse standing in global affairs.

\section{China's Political Economy and Environmental Issue}

Although many policymakers and researchers believe that environmentalism and economy are not in a zero-sum relationship (Schofer, 2006), China's political protocol with an intensive concentration on economic development in the reform years gives rise to large-scale irresponsible business activities that enormously heighten the level of consumption and exploitation of natural resources. In addition, as an offshoot of China's makeover in its political climate since 1979, decentralization in bureaucracy and jurisdiction makes it difficult to generalize the overall status quo of the environmental issue. Discrete and imbalanced distribution of political power at the local level greatly erodes the national mandates and also dictates the enforcement of the environmental policies.

\section{Conflicts between Economic Growth and Environmental Protection}

Environmental protection and its policies are often portrayed as a conflict to economic growth, because stringent regulations would constrain the scope of the industrial development, require more "green" apparatus, and cost substantial resources to process wastes and pollutants. Although some researchers contended this idea by pointing out that those pro-environmental countries can get more benefits in terms of economic growth, unfortunately, China is intentionally excluded in a cross-national statistical analysis (Schofer, 2006: p. 975) due to this country's unique and complex political and social characteristics.

The unprecedented agricultural-to-industrial and rural-tourban advancement (Ali et al., 2008; Sims, 1999) has boosted China's economy in a fast track, but the central government's concern with the environmental issue was slackened and remained irresolute in years. Under the guidelines of concentrating on economic development, industrialization is universally considered by government officials as the only path leading to modernization, a notion so called "first pollution and then remediation", which suggests an obsession with the economic development while overlooking other important social aspects, as well as the unintended aftermath that it will potentially bring about. As a consequence, China's economic growth is featured by high levels of capital investment, resource consumption, and pollutant discharge, a mode that has already been dismissed by 
most developed countries (Wu, 2011).

In China, conflicts between economic development and the environmental issue are often resolved in favor of the former (Boxer, 1989). In most areas, a lot of environmental protection endeavor is more likely succumb to economic development at a local level. Guo (2007: p. 379) observes that local economic situations play a key role in determining career advancement of local officials, and "provincial leaders with worse economic growth or fiscal contribution are more likely to be demoted or retired". As a result, the majority of the local institutions and government bureaucrats are more galvanized to boost economic growth than concerned about pollution control (Bo, 2002; Li \& Zhou, 2005; Tang et al., 1997). From their perspectives, marketization or infrastructure construction can render more direct and pronounced fiscal return, which further strengthens the legitimacy of the political support for economic development (Schwartz, 2004).

As the economy progressed rapidly, economic prosperity has taken a toll on the natural environment. China's overheated economy imposes greater demands on energy and resource consumption than ever before, which irreversibly aggravates its environmental woes. While China already has been the world's largest consumer of coal, it also has become the second largest consumer of crude oil and electricity. The controversial project of the Three Gorges Dam has provoked considerable opposition by both domestic and global environmental protection groups. Once completed, the reservoir will stretch over 350 miles upstream and the 26 turbines of the dam are able to pump out 18,200 megawatts of electricity, equivalent to almost 10 large coal-fired power stations in a single year (Cable News Network, 1997). Critics argued that the facility will be expected to jeopardize the health of massive local species and humans habitats, which will outweigh the benefits that the project is designed to produce (CNN, 1997; Jing, 2000). In addition to the deteriorating natural environment, both the metropolitan and secondary cities in China have suffered detrimental pollution, caused by rash urbanization and imbalance population concentration. According to a report by the World Bank (2007), 20 of the 30 cities with the most polluted air condition are in China. Since 1978, driven by the lure of a better fortune and education system in the urban areas, coupled with dismantled rigid residential boundaries, a sizeable influx of migrants from the countryside into the cities manifests an incredibly long-lasting upward of social mobility in contemporary China. The continuously escalating number of urban households and the rising living standards entail massive demands on water, electricity, heating, air conditioning, and transportation, which inflicts tremendous pressure on the inner-city environment in China.

\section{Changes in Political Ideology in China}

Since the collapse of the Soviet Union, China remains one of the few nations oriented by Marxism-Leninism. After it embarked on the economic reform in the late 1970s, immense changes have taken place in almost every domain of the Chinese society. It also triggers a campaign of new cognition on political ideology. On one hand, this reform that emphasizes the development of economy, science and technology does not defy much of the long held theories of Marxism; on the other hand, China has instilled new implications into this doctrine through its own distinctive way.

The reform that started in 1978 was so profound in China that this grand transformation not only reshuffled the entire economic structure, but also resulted in new social stratifications and norms. Although the economic reform undermined the prior political ideology that bolstered the perception of "proletariats revolution" (White, 1995), the post-Mao regime still echoes one of the Marxism claims, that is, labor and economic activities have served as the fundamental dynamism underlying the vicissitude of human societies (Hughes, 1995). The late Chinese top leader Deng Xiaoping not only inherited this doctrine, but also promoted a flexible and pragmatic approach to interpret and act upon most of Marxist principles. In fact, Deng also recognized that despite Marx's relentless condemnation of capitalism, Marx obviously appreciated the advances that the industrial revolution and technical changes in capitalist society had generated. One of Deng's most audacious perceptions that largely refuted leftist leadership and cult of persona was the concept of collective leadership (Soled, 1995). Moreover, a conspicuous differentiation between Mao and Deng lies in their perspectives on social values. While Mao stressed self-sacrifice, collectivism, egalitarianism, and obedience to the Communist Party and society, Deng encouraged materialistic incentives, self-interest, and pragmatism (Soled, 1995).

The failed Tian'an Men Square democratic movement ushered in a few years of stagnancy in China's economy, but soon after Deng made a historic announcement about the nation's reaffirmed stewardship and new orientation of development in 1992, China's economy rebounded. By joining the World Trade Organization (WTO) in 2001 which allowed China to fully embrace globalization, China experienced an immense takeoff in its economy and national power. More incredibly, this surge sustained for more than 10 years. Many scholars pointed out that China is well-positioned to keep this up for two more decades (Oi, 2005; Shirk, 2010). In fact, according to the United Nations, in 2010 China already overtook Japan and Germany and has become the second largest economy in the world. Meanwhile, learning the lesson from the Tian'an Men trauma, Chinese political leaders reinforced the regime by a fixation on the economic development, while maintaining cohesion of the central leadership and social stability.

\section{Political Decentralization and Its Impact on the Environmental Issue}

Since the founding of the People's Republic in 1949, China's political ideology depends on a hierarchical structure dominated by a number of conservative bureaucrats (Shirk, 2010). This led to legislation occurring in a close-knit bureaucratic entity with institutional inertia. At the national level, environmental policies must go through authorization processes of numerous bodies: the Politburo, the State Planning Commission, the Environmental Committee of the National People's Congress, the National Environmental Protection Administration (NEPA), which was renamed and reorganized as the State Environmental Protection Administration (SEPA) in 1998, and various other ministries (Jeon \& Yoon, 2006; Ross, 1988; Tilt, 2010). Among these, only the SEPA has a liaison relation with other relevant political departments (Jeon \& Yoon, 2006; Guo, 2007). For instance, SEPA collaborates with the National Statistics Bureau to compile and release an annual report that comprehensively covers a wide range of issues concerning environmental preservation. Nevertheless, SEPA does not have 
an authoritatively weighty position in the case of interest conflicts with other political organs (Sinkule \& Ortolano, 1995; Jeon \& Yoon, 2006), which obstructs collective contributions to the policymaking and jurisdiction processes.

At the local level, most municipal environmental institutions now possess an equal footing as other bureaucratic departments (Ma \& Ortolano, 2000; Smil, 1993), and this allows them to secure more funds and fortify the connections with other government units. However, they are somewhat defective in two important aspects: insufficient authority and lack of coordination among these institutions. Since they are subject to financial and personnel provision and supervision by the local governments, the power of decision making is still largely wielded by the local governments, instead of the agencies. Meanwhile, political decentralization and geographic heterogeneity create a lot of barriers for local environmental agencies to make joint efforts (Jahiel, 1997).

In spite of a non-democratic, single-party system, China's political setting is not a top-down monolithic one. As a result of the economic reform, decentralization has given considerable autonomy and flexibility to local governments and private sectors in many spheres. In the early 1980s, the state government's annual expenditures accounted for half of the total, but it has been reduced to between $27 \%$ and $34 \%$ since 1988 , which means $70 \%$ has been channeled to four local levels: province, city, county/city district, and town/village (Guo, 2007). In addition, China's vast territory and cultural heterogeneity contribute to discrepancies between national and regional bureaucracy features as well as divergent entrenched inter-regional interests that engage municipal leaders, economic and industrial bureaus, government agencies, and the environmental protection organizations (Lo \& Fryxell, 2003). As the administrative reforms and institutionalization continues, China's central leadership became less pivotal or decisive in power and resource allocation at the local level (Li \& Bachman, 1989; Guo, 2007).

Therefore, there is a disparity between political rhetoric and implementation of the policies, especially in the countryside and rural areas, where the practice of environmental edicts is often overlooked and circumvented. This leads to most of the environmental issues being addressed at a state level. In January 2011, SEPA launched an initiative targeting four prominent electric corporations nationwide, which includes shutting down certain production programs, investigating solutions for industrial pollution, and halting new construction projects (China Daily 中国日报, January 10, 2011). In fact, throughout the country there are millions of these companies that have been endorsed or connived by the local governments and/or regional environmental institutions, but only the state agencies have the potential capability to confront them with tangible measures.

Meanwhile, continuous decentralization has greatly empowered local authorities whose self-interest is directly linked with the regional economic performance. And very often local leaders find their interest in clashes with the national as well as other local interest. This divergence hampers jurisdiction of the central environmental agencies and the enforcement of the environmental policies. A report compiled by SEPA in 2005 was aborted by virtue of the debate about publishing the rankings of provincial "green GDP", a new practice to gauge economic performance while taking the environmental cost into account (China Daily 中国日报, May 12, 2005). The same thing happened in the ensuing years. This incident indicates that the efficacy of the central environmental agencies is substantially susceptible to divergent sub-national interests. In light of these constraints, although SEPA has the authority to formulate and command policy directives, it is not a powerhouse to control or oversee the implementation of the policies at the local level (Lo \& Fryxell, 2003; Schwartz, 2004).

Another important actor in play is guanxi, which literally means the network of interpersonal relationships emphasizing mutual trust and reciprocal favor (Bian, 1994). Not only do they facilitate the exchange of gratifications amid private interactions, these networks of relationships are also significant customary manners of handling political and economic interactions in China, due to the comparatively weaker institutional implementations ( $\mathrm{Li}, 2007)$. It is so ubiquitous and influential throughout China's political mechanism and cultural values that the execution of the environmental policies is seriously circumscribed by guanxi (Lo \& Fryxell, 2003).

As one of the unintended consequences of political decentralization, local protectionism, actually a type of guanxi between local governments and businesses, severely thwarts implementation of the environmental policies. As the representatives of regional interests, local government officials often have complicated connections with business leaders of local enterprises aligned by unwarranted mutual benefits. On one hand, local governments depend on industries and companies to levy tax as revenue. On the other hand, a lot of business leaders make in-roads in local authorities in order to obtain special treatment or favor that facilitates their operations. Some even attempt to cover up their infringements by falsifying documents and bribing government officials. Through these gratuitous agreements, some local governments not only acquit or protect violations of environmental standards, but also espouse new investment projects that have been explicitly outlawed by the state environmental edicts. This conspiracy between money and power underpins local protectionism, which is often immune from state interposition.

Take the construction of hydroelectric dams for example. There are approximately 45,000 mega-sized dams in the world and $45 \%$ of them are in China. The total number of mediumand small-sized dams in China even exceeds half a million, which are scattered in almost all major rivers and waterways (Wu, 2010). In most cases, the builders, dam owners, and local governments are beneficiaries in the projects. Some scientists point out that some of these establishments are absolutely redundant; more importantly, many are located in the heart of national environmental protection districts, national ecological preservation zones, and national scenery parks (Wu, 2010). With sloppy oversight by the local officials, reckless planning by the builders, and poor management by the owners, the impact that these facilities exert on the environment will be exceptionally devastating.

Some large companies use investment benefits as bait and switch to coerce local governments for the purpose of condoning their transgressions. APP Corporation financed $80 \%$ of the industrial projects in the Hainan province and also purchased 330,000 acres of natural forest from the provincial government (Wu, 2010). Not only has its paper manufacture seriously damaged the forest by extensive logging, but also through the multi-million contracts signed with the government, the company has such a direct and forceful influence on myriad local government departments and environmental protection agencies that they can mostly evade litigation for many years. Legal actions toward APP Corporation just began to take place in 
2010.

The challenging application of the new "green GDP" initiative also indicates that local protectionism is one of the road blocks to the enforcement of environmental measures. Intended as an indispensable standard in assessing provincial leaders' political performance, the practice of "green GDP” is actually sidelined in most areas, and none of the leaders was penalized or demoted on account of the environmental issue.

\section{China's Civil Society and Public Awareness of the Environmental Issue}

Although social media, researchers, and environmental NGOs who share a common concern toward the issue of environmental protection were able to have an impact in the agenda set up for mass cooperation at both domestic and international levels (Jeon \& Yoon, 2006), this progress is still explicitly hindered by the more powerful political bulwark.

\section{China's Environmental Civil Society}

Civil society, the existence of autonomous, non-governmental organizations polishing the rough edges of our society, expands the sphere of people's freedom and autonomy in their social life. The dichotomy between civil society and government indicates that civil society is an ideally structured domain devoid of state's control and arbitration.

A much more mature and effective environmental protection mechanism in many developed and democratic countries can be attributed to their relatively robust public support and a more advanced civil society.

Although globalization and information technology introduce a large volume of international ideas to the Chinese and many of them are conscious of a burgeoning civil society in China and even strive to promote it, its growth is far from strong enough to trigger political revolution against the ruling party. Despite the attempts that Chinese leadership at both the national and sub-national levels has been making to streamline bureaucratic administration through reforms (Forster, 2006), political guidelines are still largely inclined to quash public grievances on miscellaneous social problems. In addition, by shifting public attention to economic prosperity in tandem with police coercion and even occasional use of military crackdown (MacKinnon, 2008), the Chinese Communist Party has successfully dampened the development of civic society in China. In such an authoritarian regime, publicly organized demonstrations and protests against environmental pollution are greatly inhibited, civic discourse and complaints about the environmental issue are discouraged, and reports of cases of environmental infractions via media are mostly censored.

Recent research found a new direction of public counteraction toward environmental crisis (Jing, 2000; O’Brien \& Li, 2006; Tilt, 2010). By mobilizing citizens' support and employing lenient rhetoric to exert influence on government, this kind of "peaceful" resistance exists and operates at the periphery of the formal political oversight. Organized protests against environmental damage have been on the rise and government became more tolerant of this kind of confrontation, provided that it is restricted on a local level and small in scale (Oi, 2001; Tilt, 2010). One most significant and inspiring victory accomplished by civic movements took place in 2006 in Xiamen, one of the Special Economic Development Zones located in southeastern China. Xiamen is reputed for its scenery coastal lines and good environmental quality throughout the years. Thanks for the massive opposition by the Xiamen citizens of all social levels, a large-scale petrochemical factory to be invested and operated by Taiwanese was forced to alter its original blueprint and eventually was established in another area (Pan, 2006).

In spite of these encouraging progresses, the existence of criticism about the status quo is mainly sporadic and confined in a "safety zone", where the voice of the grass-roots remains flimsy and compartmentalized (Schofer, 2008). Civic engagement and public support for environmental protection invariably find it difficult to penetrate into China's political system as an institutional factor shaping legislation and administration. The legal framework for public participation in China, albeit progressive in the long run, is ill-defined and inconsistently enforced.

\section{Environmental NGOs in China}

Independent non-official environmental organizations have emerged since the 1990s. Focusing on education and volunteerism, they disseminate information regarding environmental sustainability and organize promotion activities, such as tree planting and public forum. Friends of Nature is the largest among these groups with 350 members since it was founded in 1994 (Knup, 1997). The globally prominent environmental NGO, Green Peace, has environmental programs in more than 40 countries with 2.5 million voluntary members worldwide. Its first Chinese branch was established in Beijing in 2002. Its missions in China range from initiating a wide range of programs arousing public awareness to enlisting volunteers, from providing businesses with environmental counseling to reporting cases that violate environmental regulations. At the same time, college student groups promoting environmentalism have made an appearance on campus. By 1997, there were over 20 such student organizations in Beijing and at least 10 in other parts of the nation (Jahiel, 1997).

There were over 2000 registered environmental NGOs in China by 2000 and many of them are best described as "governmental non-governmental organizations" (Schwartz, 2004: p. 36). These are not the real NGOs in a strict sense, because they are mostly established and funded by government agencies. In this case, these government-sponsored NGOs should take on the responsibilities of educating government officials at various levels and broadening their scope of knowledge of the environmental issue.

Regardless of how promising these organizations may appear, NGOs are commonly not strong enough to influence policymaking and most NGOs are faced with mounting constraints, such as insufficient funding and staffing, lack of public support, limited resources, antagonism from the industries, and restrictions and surveillance imposed by the state and/or local governments.

\section{Public Awareness of the Environmental Issue}

Generally speaking, public awareness of environmental protection in China lags far behind those developed countries. The majority of individuals are less aware of the need to preserve environment and some rural people even never heard of the term "environmental protection" (Tilt, 2010). Some research studies found out that the majority of China's expanding elite and middle class are very content with their privileged social status and are unwilling to sabotage their financial gains in 
exchange of a subversion of the existing political system (Tang, 2005).

This ignorance and nonchalance stem from people's anxiety predominantly about the economic realities. A large proportion of the rural population is still struggling under the poverty line and having to meet their basic life needs is placed as the priority. In addition, spurred by the goals of achieving economic success and enhancing social standing, especially during the past five years when housing prices in the major cities have been skyrocketing, most urbanites are literally pushed to strive laboriously for a better affordability to become homeowners.

That explained why the United Nations Climate Change Conference, widely known as Copenhagen Summit, was given so little coverage in most of the local media, while many Chinese TV talk shows and online forums are more likely to discuss the issues like motor vehicle purchase, housing prices, education, and unemployment. In the perceptions of most citizens, environmental protection is more of a political issue that should be left for the government to deal with, and the daily efforts of preserving energy and reducing carbon footprints are considered luxury afforded only by the urban elites. This widely held mindset exacerbates the marginal public support for environmental protection.

\section{Conclusion}

Overall, the environmental issue in China is entangled with multifaceted national and local political and social characteristics of complex nature. China's political agendas for environmental protection are often very ambiguous with little consideration in geographic heterogeneity and social stratifications (Muldavin, 2000; Oakes, 1996).

Realization of the severe cost on environment caused by the rapid economic growth should be a key step to redress the economic-oriented political strategies and authoritative stewardship in this matter. If the economic interests of industries and government in China continue to take precedence over the environmental issue, it will be an ongoing battle between economic growth and public values. Given the subordinate position of the environmental agencies, legislation and enforcement of the environmental policies should be hinged upon the authority of the state and local governments. Meanwhile, by adopting "green GDP" (Ali et al., 2008), industrial leaders should employ energy-efficient production mechanism and amend the ways in which economic activities proceed, such as manufacturing, resource distribution, and mass consumption (Ali et al., 2008; Muldavin, 2000; Sinkule \& Ortolano, 2000).

With relatively weak environmental agencies, underdeveloped NGOs, and disorganized and feeble public support in China, political climate and stewardship of the state government became exceptionally decisive in the environmental issue. Chinese contemporary history proves that government-driven public movements could be an effective way of developing environmental civil society in China. Therefore, government accountability should be emphasized and fortified to facilitate civil campaigns of preserving environment (Pan, 2006).

Admittedly, similar to most developing countries, China is challenged by a host of disadvantages and constraints. Given the country's low per capita income, there is a shortage of resources at government's disposal, and many other realms, such as infrastructure construction and social welfare reform, are in much greater need of imperative investment and attention. All these marginalize the endeavor on saving China's environment. With China's increasingly prominent status in the international arena, finding a balance between economic growth and environmental protection not only has far-reaching implications for China, but also serves as a potential model or paradigm for other developing countries.

The China's environmental issue is a long-term, arduous undertaking that entails prudent and active promotion by government leadership, adamant legislation and enforcement at both the national and local levels, elevation of the authority of the environmental agencies, industrial compliance with the environmental standards and investment in new clean technologies, and a mature civil society with influential and organized public support. These are the fundamental building blocks that need to be worked out in the cause of saving the environment in China.

\section{REFERENCES}

Ali, R., Olden, K., \& Xu, S. Q. (2008). Community-based participatory research: A vehicle to promote public engagement for environmental health in China. Environmental Health Perspectives, 116, 1281-1284. http://dx.doi.org/10.1289/ehp.11399

Banister, J. (1998). Population, public health, and the environment in China. The China Quarterly, 156, 989-990. http://dx.doi.org/10.1017/S0305741000051420

Bendix, R. (1987). Reflections on modern western states and civil society. Research in Political Sociology, 3, 1-38.

Bian, Y. (1994). Work and inequality in urban China. Albany, NY: State University of New York Press.

Brundtland, G. H. (1987). Our common future-The report of the world commission on environment and development. Oxford: Oxford University Press.

Bo, Z. (2002). Chinese provincial leaders: Economic performance and political mobility since 1949. Amonk, NY: M.E. Sharpe.

Boxer, B. (1989). China's environmental prospects. Asian Survey, 29, 669-686. http://dx.doi.org/10.2307/2644673

China Daily 中国日报 (2005). The Chinese government’s investment on environmental protection and its outcome. 中国政府对环境保护 的措施及效果.

China Daily 中国日报 (2011). Tracking the root of China’s environmental problems. 追溯中国环境问题的根源.

Cable New Network (CNN) (2010). China's three gorges damEcon-boon or cesspool? 1997.

Foster, K. (2006). Improving municipal governance in China. Modern China, 32, 221-250. http://dx.doi.org/10.1177/0097700406286188

Guo, G. (2007). Retrospective economic accountability under authoritarianism. Political Research Quarterly, 60, 378-390. http://dx.doi.org/10.1177/1065912907304501

Hughes, J. A. (1995). Understanding classical sociology. Thousand Oaks, CA: Sage Publications.

Jahiel, A. R. (1997). The contradictory impact of reform and environmental protection. The China Quarterly, 149, 81-103. http://dx.doi.org/10.1017/S0305741000043642

Jahiel, A. R. (1998). The organization of environmental protection in China. The China Quarterly, 156, 757-787. http://dx.doi.org/10.1017/S030574100005133X

Jeon, H., \& Yoon, S. (2006). From international linkages to internal divisions in China: The political response to climate change negotiations. Asian Survey, 46, 846-866. http://dx.doi.org/10.1525/as.2006.46.6.846

Jing, J. (2000). Environmental protests in rural China. In E. J. Perry, \& M. Selden (Eds.), Chinese society: Change, conflict and resistance (pp. 143-160). London: Routledge.

Keane, J. (1988). Democracy and civil society. London: Verso.

Knup, E. (1997). Environmental NGOs in China: An overview. Chinese Environmental Series, Washington, DC: Woodrow Wilson Center.

Li, C., \& Bachman, D. (1989). Localism, elitism, and immobilism: 
Elite formation and social change in post-Mao China. World Politics, 42, 64-94. http://dx.doi.org/10.2307/2010571

Li, H., \& Zhou, L. (2005). Political turnover and economic performance: The incentive role of personnel control in China. Journal of Public Economics, 89, 1743-1762. http://dx.doi.org/10.1016/j.jpubeco.2004.06.009

$\mathrm{Li}, \mathrm{X}$. (2007). Adaptation to a new Chinese environment: A study of foreign invested enterprises in China. Journal of the Washington Institute of China Studies, 2, 12-32.

Lo, C., \& Fryxell G. (2003). Enforcement styles among environmental protection officials in China. Journal of Public Policy, 23, 81-115. http://dx.doi.org/10.1017/S0143814X03003040

Lo, C. P., Yip, C., \& Cheung, K. (2000). The regulatory style of environmental governance in China: The case of EIA regulation in Shanghai. Public Administration and Development, 20, 305-318. http://dx.doi.org/10.1002/1099-162X(200010)20:4<305::AID-PAD1 28>3.0.CO;2-I

Ma, X., \& Ortolano, L. (2000). Environmental regulation in China: Institutions, enforcement, and compliance. New York: Rowan and Littlefield Publishers.

MacKinnon, R. (2008). Flatter world and thicker walls? Blogs, censorship and civic discourse in China. Public Choice, 134, 31-46. http://dx.doi.org/10.1007/s11127-007-9199-0

Muldavin, J. (2000). The paradoxes of environmental policy and resources management in reform-era China. Economic Geography, 76, 244-271. http://dx.doi.org/10.2307/144292

Oakes, T. (1996). Eating the food of the ancestors: Peace, tradition, and tourism in a Chinese frontier river town. Ecumene, 6, 123-145. http://dx.doi.org/10.1191/096746099701556132

O’Brien, K., \& Li, L. (2006). Rightful resistance in rural China. Cambridge: Cambridge University Press. http://dx.doi.org/10.1017/CBO9780511791086

Oi, J. (2005). Patterns of corporate restructuring in China: Political constraints on privatization. The China Journal, 53, 115-136. http://dx.doi.org/10.2307/20065994

Palmer, M. (1998). Environmental regulation in the People's Republic of China: The face of domestic law. The China Quarterly, 156, 788808. http://dx.doi.org/10.1017/S0305741000051341

Pan, Y. (2006). The environment needs public participation. China Dialogue.

http://www.chinadialogue.net/article/show/single/en/604-the-environ ment-needs-public-participation

Ross, L. (1988). Environmental policy in China. Bloomington, IN: Indiana University Press.
Schofer, E. (2006). Environmentalism, globalization and national economics, 1980-2000. Social Forces, 85, 965-991.

http://dx.doi.org/10.1353/sof.2007.0024

Schwartz, J. (2004). Environmental NGOs in China: Roles and limits. Pacific Affairs, 77, 28-49.

Shirk, S. (2007). China: Fragile superpower. New York: Oxford University Press.

Sims, H. (1999). One-fifth of the sky: China's environmental stewardship. World Development, 27, 1227-1245. http://dx.doi.org/10.1016/S0305-750X(99)00051-0

Sinkule, B., \& Ortolano, J. (1995). Implementing environmental policy in China. London: Praeger.

Soled, D. (1995). China, a Nation in Transition. Washington, DC: Congressional Quarterly Inc.

Smil, V. (1993). China's environmental crisis: An inquiry into the limits of national development. Armonk, NY: M.E. Sharpe.

State Environmental Protection Administration 国家环境保护总局 (2004). The report of Chinese green national GDP and economy in 2004. Beijing. 中国 2004 年绿色 GDP 经济报告. 北京.

Tang, H. (2008). Xiamen PX: A turning point? China Dialogue. http://www.chinadialogue.net/article/show/single/ch/1626

Tang, S., Lo, C., Lo, J., \& Cheung, K. (1997). Institutional constraints on environmental management in urban China: Environmental impact assessment in Guangzhou and Shanghai. The China Quarterly, $152,863-874$.

Tang, W. (2005). Public opinion and political change in China. Palo Alto, CA: Stanford University Press.

Tilt, B. (2010). The struggle for sustainability in rural China. New York: Columbia University Press.

Wan, M. (1998). China's economic growth and the environment in the Asia-Pacific region. Asian Survey, 38, 365-378. http://dx.doi.org/10.2307/2645412

White, G. (1995). Chinese socialism and the transition to capitalism. In C. Beiwener et al. (Eds.), Marxism in the postmodern age (pp. 343351). New York: the Guilford Press.

World Bank (2007). Cost of pollution in China: Economic estimates of physical damages. Washington, DC: World Bank. http://siteresources.worldbank.org/INTEAPREGTOPENVIRONME NT/Resources/China_Cost_of_Pollution.pdf

Wu, W. (2010). Combating the environmental problems: Sources and suggestions. China Daily. 环境问题的根源和对策. 中国日报.

Zweig, D., \& Bi, J. (2005). China’s global hunt for energy. Foreign Affairs, 84, 25-38. http://dx.doi.org/10.2307/20031703 